\section{Dose-response relationships in gene expression profiles in a harbor seal B lymphoma cell line exposed to $17 \alpha$-ethinyl estradiol}

\author{
Christine Kleinert, ${ }^{1}$ \\ Matthieu Blanchet, ${ }^{1}$ François Gagné, ${ }^{2}$ \\ Michel Fournier ${ }^{1}$
}

${ }^{1}$ INRS-Institut Armand-Frappier, Laval

(QC); ${ }^{2}$ Saint-Laurent Centre,

Environment Canada, Montreal (QC),

Canada

\begin{abstract}
The determination of changes in gene expression profiles with xenobiotic dose will allow identifying biomarkers and modes of toxicant action. The harbor seal (Phoca vitulina) 11B7501 B lymphoma cell line was exposed to $1,10,100,1000,10,000$, or $25,000 \mu \mathrm{g} / \mathrm{L} 17 \alpha$-ethinyl estradiol $\left(\mathrm{EE}_{2}\right.$, the active compound of the contraceptive pill) for $24 \mathrm{~h}$. Following exposure, RNA was extracted and transformed into cDNA. Transcript expression in exposed vs. control lymphocytes was analyzed via RT-qPCR to identify genes with altered expression. Our analysis indicates that gene expression for all but the reference gene varied with dose, suggesting that different doses induce distinct physiological responses. These findings demonstrate that RT-qPCR could be used to identify immunotoxicity and relative dose in harbor seal leukocytes.
\end{abstract}

\section{Introduction}

Harbor seals are exposed to various anthropogenic stressors in the environment due to their coastal habitat, e.g. chemical pollution, litter (plastics and nanoparticles), noise, and climate change. ${ }^{1-3}$ Since exposure to persistent organic pollutants and metals has been shown to suppress the seal's immune system, ${ }^{4,5}$ it is important to understand the relative contributions of other stressors to immunosuppression as well.

Pharmaceuticals are a compound class that has only recently been analyzed for its immunosuppressive potential in marine mammal leukocytes. ${ }^{6,7}$ The synthetic estrogen $17 \alpha$-ethinyl estradiol $\left(\mathrm{EE}_{2}\right)$, which is the active compound of the contraceptive pill, has been the focus of this study. Firstly, it is an environmental xenobiotic and frequently found in municipal effluents and surface waters. ${ }^{8} \mathrm{EE}_{2}$ was found at concentrations up to $42 \mathrm{ng} / \mathrm{L}$ in effluent samples from Ontario, ${ }^{9}$ up to $831 \mathrm{ng} / \mathrm{L}$ in surface water samples from the USA ${ }^{10}$ and at concentrations up to $2.32 \pm 1.45 \mu \mathrm{g} / \mathrm{L}$ in plasma of free-ranging neonate bull shark (Carcharhinus leucas) from Florida with the latter indicating accumulative potential. ${ }^{11}$ Secondly, $\mathrm{EE}_{2}$ has previously affected lymphocyte proliferation and the cell cycle of the harbor seal 11B7501 B lymphoma cell line and harbor seal peripheral blood mononuclear cells (Kleinert et al. T lymphocyte-proliferative responses of harbor seal (Phoca vitulina) PBMCs exposed to pharmaceuticals in vitro; 2017; unpublished data). ${ }^{6}$ Lastly, B lymphocytes and lymphomas are regulated by estrogens through estrogen receptors (ER $\alpha$ and $E R \beta)$ in mammals. ${ }^{12,13}$ An active ERß receptor acts as an anti-proliferative and pro-apoptotic stimulus in non-Hodgkin lymphoma in humans. ${ }^{14}$

The model used in this study was the harbor seal 11B7501 B lymphoma cell line. This lymphoma cell line is an ideal proxy for immunocompetence assessments in marine mammals since confounding factors like physiological state and inflammation of an individual are of no concern.

New molecular biomarkers have recently been developed to identify early biological effects using minimally invasive blood samples. ${ }^{15-17}$ Since pharmaceuticals are designed to have a low acute toxicity, these potentially more sensitive methods might be more relevant in assessing immunotoxicity for this class of compounds and help infer underlying mechanisms of toxic action. The objectives of this study were to determine the immunomodulation and cytotoxicity of $\mathrm{EE}_{2}$ and gene expression profiles in a harbor seal B lymphoma cell line.

\section{Materials and Methods}

The harbor seal 11B7501 B lymphoma cell line (CRL-1940 purchased from ATCC, Manassas, VA) was maintained as previously described. ${ }^{18} 17 \alpha$-ethinyl estradiol $\left(\mathrm{EE}_{2}\right)$ was dissolved in dimethyl sulfoxide (DMSO) (both Sigma-Aldrich, Oakville, Canada). The final concentration of DMSO in the samples was $0.1 \%$.

For the in vitro exposures, $1 \times 10^{6}$ of cells were incubated with $\mathrm{EE}_{2}$ in 24-well plates for $24 \mathrm{~h} . \mathrm{EE}_{2}$ concentrations were 0 , $1,10,100,1000,10,000$, or $25,000 \mu \mathrm{g} / \mathrm{L}$. Concentrations ranging from 12,500 to $25,000 \mu \mathrm{g} / \mathrm{L}$ have previously affected the lymphocyte proliferation and cell cycle of the 11B7501 cell line. ${ }^{6}$ We chose four additional lower concentrations to assess if RTqPCR is a more sensitive method for detection of immunomodulation. In a parallel set of experiments the cell line was exposed to
Correspondence: Christine Kleinert, INRSInstitut Armand-Frappier, Edifice 18, 531 Blvd. des Prairies, Laval (QC) H7V 1B7, Canada.

Tel.: +1.438.393.7855

E-mail: kleinertchristine@gmail.com

Key words: Immunotoxicology; Phoca vituli$n a ;$ RT-qPCR; $\mathrm{EE}_{2}$.

Acknowledgements: the Research Chair in Environmental Immunotoxicology (MF) supported this study. We want to also thank Professor Patrick Labonté from the INRS-IAF for lending us equipment and lab space to validate the primers.

Contributions: CK planned and conducted experiments, wrote manuscript; MB designed primers, planned experiments; FG supervised the project, corrected manuscript; MF provided funding and lab space.

Conflict of interest: the authors declare no conflict of interest.

Received for publication: 11 March 2017.

Revision received: 19 April 2017.

Accepted for publication: 28 April 2017.

This work is licensed under a Creative Commons Attribution NonCommercial 4.0 License (CC BY-NC 4.0).

(C) Copyright C. Kleinert et al., 2017 Licensee PAGEPress, Italy

Journal of Xenobiotics 2017; 7:6702

doi:10.4081/xeno.2017.6702

the same concentrations of $\mathrm{EE}_{2}$ in the presence of $5 \mu \mathrm{g} / \mathrm{mL}$ of the mitogen lipopolysaccharide (LPS). LPS activated B lymphocytes non-specifically (induced proliferation) and was meant to simulate the cell activity for proliferation as if under pathogen exposure.

RNA was extracted using the Aurum total RNA kit (Bio-Rad, Mississauga, ON). NanoDrop-normalized (A260 nm) levels of total RNA were reverse transcribed with the iScript cDNA synthesis kit (Bio-Rad, Mississauga, ON). cDNA were used for quantitative polymerase chain reaction (qPCR) using Ssofast Evagreen supermix (Bio-Rad, Mississauga, ON). qPCR was initiated with $95^{\circ} \mathrm{C}$ for $30 \mathrm{~s}$, followed by 40 cycles with denaturation at $95^{\circ} \mathrm{C}$ for $5 \mathrm{~s}$, and the primer specific annealing temperature $\left(62^{\circ} \mathrm{C}\right)$ for $15 \mathrm{~s}$. Melting curves were created by denaturation at $95^{\circ} \mathrm{C}$ followed by 61 steps during which the temperature was increasing steadily for $0.5^{\circ} \mathrm{C}$ every $5 \mathrm{~s}$, starting at $65^{\circ} \mathrm{C}$ and ending at $95^{\circ} \mathrm{C}$, to exclude the measurement of non-specific PCR products and primer dimers and to determine true amplification. Results were 
analyzed using the comparative $\mathrm{Ct}$ method. Primers are shown in Table 1.

The reference gene $32 \mathrm{M}$ was evaluated for its stability with bestkeeper (stability value $=0.073$ ) and was chosen to normalize mRNA transcription levels of the genes of interest. Genes of cells exposed to $\mathrm{EE}_{2}$ only were normalized with the $\beta 2 \mathrm{M} 0 \mu \mathrm{g} / \mathrm{L} \mathrm{EE}_{2}$ negative control, whereas genes of cells exposed to $\mathrm{EE}_{2}$ and LPS were normalized with the $32 \mathrm{M} 0 \mu \mathrm{g} / \mathrm{L} \mathrm{EE}_{2}+\mathrm{LPS}$ negative control.

Results are obtained from two independent experiments with two technical replicates for each sample.

Viability assays were set up in parallel to observe if $\mathrm{EE}_{2}$ concentrations were cytotoxic to the 11B7501 B lymphoma cell line. After $24 \mathrm{~h}$, viability of cells was evaluated by adding $0.8 \mu \mathrm{g} / \mathrm{mL}$ propidium iodide (PI) (Sigma-Aldrich, Oakville, Canada) to the cell suspension. A FACSCalibur (Becton Dickinson, San Jose, CA, USA) with an aircooled argon laser providing an excitation at $488 \mathrm{~nm}$ was used. For each sample 5000 events were acquired at a fluorescence emission of $620 \mathrm{~nm}$ (FL3). The cell population was electronically gated in a FSC/SSC dot plot and the fluorescence frequency distribution histogram was obtained. The percentage of dead cells was determined as the proportion of cells with an elevated fluorescence using a marker. Data collection and analysis were performed with the CellQuest Pro software (Version 4.0.1). The results were expressed in percentage of viable cells.

Differences between controls and treated groups were evaluated by one-way and two-way ANOVA followed by Dunnett's post hoc test. To evaluate correlations of inter-relationships of genes of interest a Spearman rank order correlation analysis was conducted and results are summarized in Table 3. The calculations were performed using GraphPad Prism 6 for Mac (GraphPad Software). The level of significance was set at $\mathrm{P} \leq 0.05$.

\section{Results and Discussion}

A range of eight immune-relevant (CD9, IFN $\gamma$, LYN1, MAPKK3, SLAM, TGFß1), pollutant-associated (AHR) and stress (HSP70) biomarkers as well as a reference gene $(ß 2 \mathrm{M})$ were selected to analyze differential gene expression in the harbor seal 11B7501 B lymphoma cell line exposed to $\mathrm{EE}_{2}$. We limited our choice of genes to sequences that have already been validated in the harbor seal.

To obtain an overview of potential effects on the mRNA expression level of the chosen genes, we analyzed the control samples and the highest exposure concentration of $\mathrm{EE}_{2}(25,000 \mu \mathrm{g} / \mathrm{L})$ for the genes of interest (Figure 1A). The mRNA expression of all but one $(B 2 \mathrm{M})$ gene was impacted at $25,000 \mu \mathrm{g} / \mathrm{L} \mathrm{EE}_{2}$. Genes at this concentra- tion were both up- and downregulated. Lymphocytes exposed to $\mathrm{EE}_{2}$ without stimulation from LPS downregulated four out of five genes (Table 2). Lymphocytes exposed to $\mathrm{EE}_{2}$ and the mitogen LPS were more likely to have changes in gene expression, and genes were mainly upregulated (6 of 9) (Table 2).

HSP70 protects proteins from stress by aiding protein folding. HSP70 mRNA was upregulated two-fold compared to controls upon exposure to $\mathrm{EE}_{2}$ alone as well as $\mathrm{EE}_{2}$ and LPS (Table 2). Since HSP70 showed the most marked change in gene expression of all genes tested, we further evaluated the remaining exposure concentrations. The analysis revealed that HSP70 was induced only at the highest concentration (Figure 1B). Previous studies in harbor seal blood demonstrated negative (cadmium, Cd) and positive (lead, $\mathrm{Pb}$ ) correlations between trace metal concentrations in blood and HSP70 expression. ${ }^{1}$ These trends are in accordance with previous work that demonstrated that xenobiotic exposure could lead to immunosuppression or acute and chronic inflammatory processes that could cause hypersensitivities or autoimmune diseases. ${ }^{19}$ When assessing HSP70 in blood of free-ranging animals it has to be taken into account that capture and sampling stress might alter the physiological levels of HSP70 in these animals. HSP70 and cortisol were correlated in adult seals, and habituation (i.e. decreasing levels of HSP70 over

Table 1. Primers used for qPCR analysis. All primers are listed from 5' to 3'.

\begin{tabular}{lll}
\hline Gene & Description & Forward (F) \& Reverse (R) Primers \\
B2M & & \\
Genes of Interest & Component of MHC class I molecules & F' CTA CGT GTC AGG GTT CCA T \\
AHR & & R' TGC TTT ACA CGG CAG CTA \\
CD9 & Regulator of cytochrome P450 & \\
& & F' ATA CAG AGT TGG ACC GTT TG \\
\hline HSP70 & Regulator of cell development, activation, growth and motility & F' TCT TTG GCT TCC TCT TGG T \\
IFNy & Aids with protein folding under heat or chemical stress & F' GCA ACG TGC TCA TCT TTG A \\
& & R' AGC CTG TTG TCA AAG TCC T \\
LYN1 & Cytokine; activates macrophages; induces MHC class Il expression & F' CAA GGC GAT AAA TGA ACT CA \\
MAPKK3 & R' CGG CCT CGA AAC AGA TTC \\
\hline SLAM & Key enzyme in regulation of cell activation in hematopoietic cells & F' CAA GGG AAG GTG CCA AAT T \\
& & R' GAC CAT ACA TCA GAC TTA ATC G \\
TGFß1 & F' TTG GTG GAT TCT GTA GCC A \\
& Phosphorylates mitogen-activated protein kinase (MAPK) & R' AAG CCC ACA CAT CAG ACT T \\
\hline
\end{tabular}

B2M=beta-2 microglobulin; AHR=aryl hydrocarbon receptor; CD9=Cluster of differentiation 9; HSP70=70 kDa heat shock protein; IFNY=interferon gamma; LYN1=Lck/Yes novel tyrosine kinase; MAPKK3=mitogenactivated protein kinase kinase; SLAM=signaling lymphocytic activation molecule; TGFß1=transforming growth factor beta 1 
time) was observed in rehabilitation processes where seals have been handled frequently. ${ }^{1,15,17,20}$ Moreover, effects on HSP70 expression strongly correlated with AHR expression $(\mathrm{r}=0.606)$ and $\mathrm{IFN} \gamma$ expression $(\mathrm{r}=0.743)$ (Table 3).

Interferon gamma (IFN $\gamma$ ) and signaling lymphocytic activation molecule (SLAM) are associated with susceptibility to mammalian infectious diseases. ${ }^{21}$ IFN $\gamma$ is a cytokine that activates macrophages and induces class II major histocompatibility complex (MHC II) expression. In our study, IFN $\gamma$ expression was upregulated after exposure to $25,000 \mu \mathrm{g} / \mathrm{L} \mathrm{EE}_{2}+\mathrm{LPS}$, but not when the mitogen LPS was not present (Figure 1A, Table 2). Since the +LPS negative control was identical to the -LPS negative control, this upregulation can be attributed to a combined effect of $\mathrm{EE}_{2}$ with LPS. Furthermore, effects on IFN $\gamma$ expression displayed strong correlations with pattern changes in AHR expression $(\mathrm{r}=0.606)$ and HSP70 expression ( $\mathrm{r}=0.743$ ) (Table 3).

SLAM is a surface receptor on activated
$\mathrm{B}$ and $\mathrm{T}$ lymphocytes. In our study, its expression was not affected by $25,000 \mu \mathrm{g} / \mathrm{L}$ $\mathrm{EE}_{2}$ alone, but it was one of the few genes that was significantly downregulated when additionally exposed to LPS. It has been shown to enhance IFN $\gamma$ production, and is the primary cellular receptor for Morbillivirus. $^{22}$ Interestingly, SLAM and IFN $\gamma$ mRNA levels showed inverse trends in regulation after exposure to $\mathrm{EE}_{2}$ and LPS. While the exposure to the $\mathrm{EE}_{2}$ or LPS alone did not change the mRNA expression, the additional stimulus and stress of a potential pathogen (LPS) impacted the B lymphoma cell line. The increase in IFN $\gamma$ can therefore be attributed to the presence of LPS, and not due to an increased production due to SLAM. The Spearman rank order correlation analysis revealed negative correlations with expression of SLAM and LYN1 $(\mathrm{r}=-0.680)$ as well as MAPKK3 $(\mathrm{r}=-0.568)$ (Table 3$)$.

Tyrosine-protein kinase LYN1 is involved in the regulation of cell activation of hematopoietic cells. LYN1 expression was upregulated after exposure to
Table 2. Summary of significant gene expression changes in the 11B7501 B lymphoma cell line. Up- or downregulation is described as the percentage of expression relative to the negative controls of $B 2 \mathrm{M}$. The $32 \mathrm{M}$ negative control (-EE $2 /-\mathrm{LPS})$ was used to normalize genes exposed to $\mathrm{EE}_{2}$ only, whereas the $\$ 2 \mathrm{M}$ negative control $\left(-\mathrm{EE}_{2} /+\mathrm{LPS}\right)$ was used to normalize genes exposed to $\mathrm{EE}_{2}$ and LPS.

\begin{tabular}{lcc} 
Genes $25000 \mu \mathrm{g} / \mathrm{L} \mathrm{E}_{\mathrm{E} 2}$ & $\begin{array}{c}25000 \mathrm{jg} / \mathrm{L} \mathrm{EF}_{2} \\
+5 \mathrm{jg} / \mathrm{mL} \mathrm{LPS}\end{array}$ \\
AHR & $\downarrow 81 \pm 12 \%$ & $\uparrow 120 \pm 13 \%$ \\
CD9 & & $\downarrow 59 \pm 7 \%$ \\
\hline HSP70 & $\uparrow 191 \pm 36 \%$ & $\uparrow 228 \pm 80 \%$ \\
IFNY & & $\uparrow 141 \pm 13 \%$ \\
\hline LYN1 & $\downarrow 63 \pm 14 \%$ & $\uparrow 142 \pm 17 \%$ \\
MAPKK3 & & $\uparrow 163 \pm 48 \%$ \\
SLAM & & $\downarrow 63 \pm 29 \%$ \\
TGFß1 & $\downarrow 62 \pm 15 \%$ &
\end{tabular}

$\mathrm{EE}_{2}=17 \alpha$-ethinyl estradiol; LPS=lipopolysaccharide; AHR=aryl hydrocarbon receptor; $\mathrm{CD} 9=$ Cluster of differentiation 9; HSP70=70 kDa heat shock protein; IFNY=interferon gamma; LYN1=Lck/Yes novel tyrosine kinase; MAPKK3=mitogen-activated protein kinase kinase; SLAM=signaling lymphocytic activation molecule; TGFß1=transforming growth factor beta 1 .

A

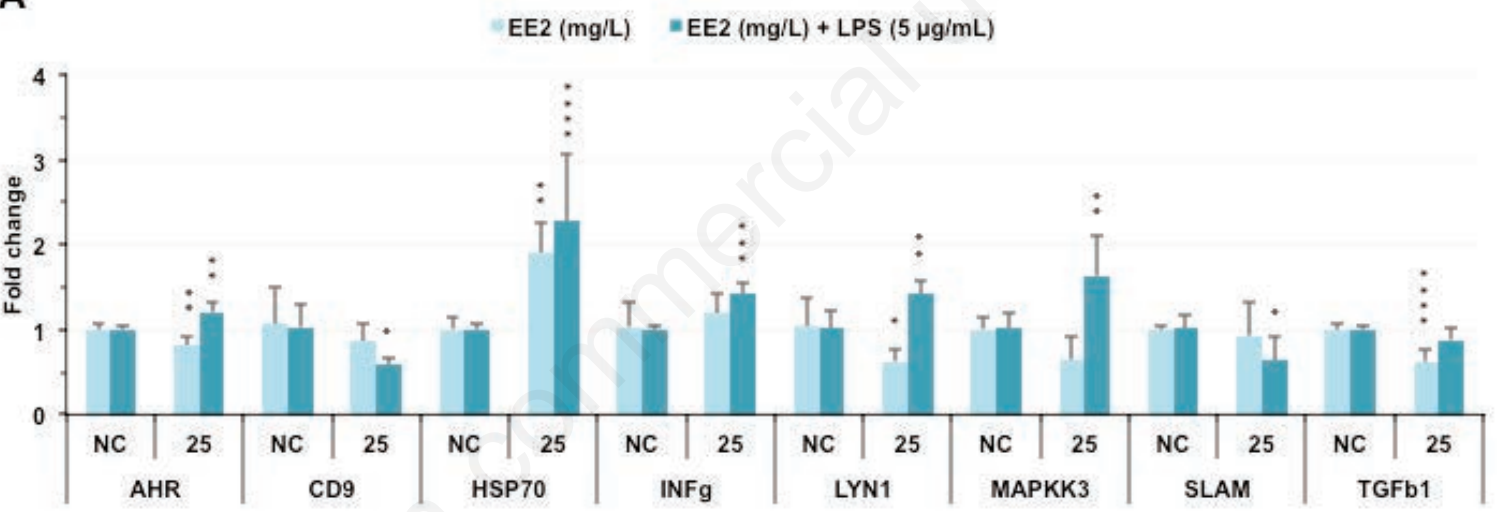

B

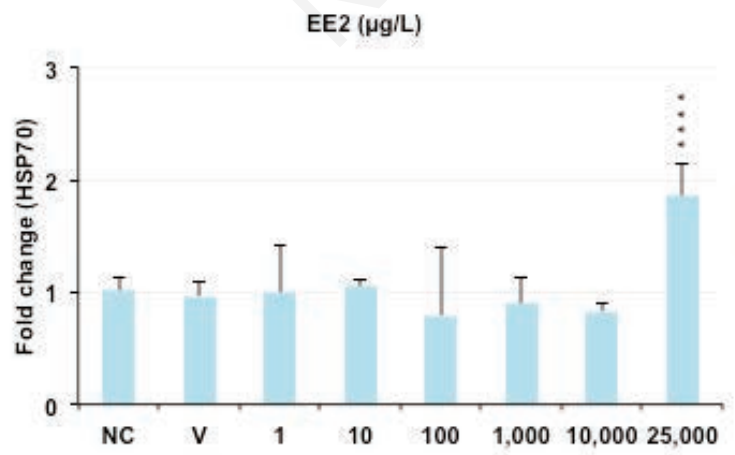

C

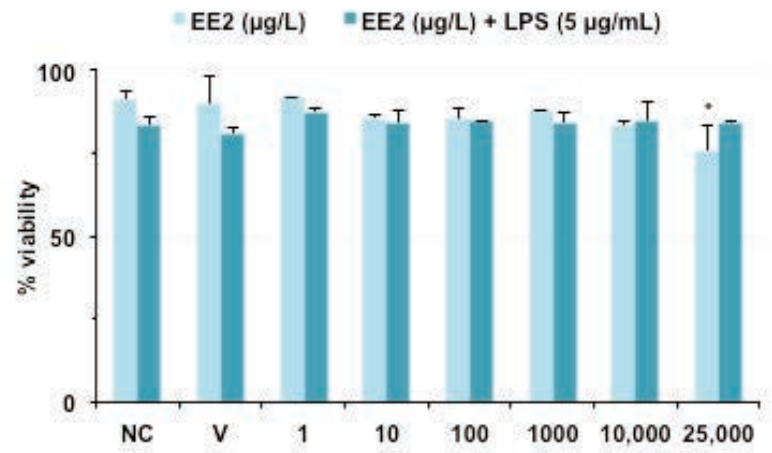

Figure 1. (A) Fold change in gene expression after $24 \mathrm{~h}$ exposure to 0 (NC) and $25 \mathrm{mg} / \mathrm{L} \mathrm{EE}$ as measured by $\mathrm{qPCR}$. A fold change of 1 indicated no change in comparison to the reference gene $32 \mathrm{M}$. (B) Dose-response gene expression changes of HSP70 mRNA after $24 \mathrm{~h}$ exposure to $\mathrm{EE}_{2}$. (C) Viability of the $11 \mathrm{~B} 7501 \mathrm{~B}$ lymphoma cell line after $24 \mathrm{~h}$ exposure to $\mathrm{EE}_{2}$ and $\mathrm{EE}_{2}+\mathrm{LPS} \mathrm{Results}$ are expressed as Mean \pm SD. (* $\mathbf{p}<0.05$; ${ }^{* *} \mathbf{p}<\mathbf{0 . 0 1}$; ${ }^{* * *} \mathbf{p}<0.001$; $\left.{ }^{* * * *} \mathbf{p}<\mathbf{0 . 0 0 0 1}\right)$. Abbreviations: $\mathrm{EE}_{2}=17 \alpha$-ethinyl estradiol; LPS=lipopolysaccharide; $B A C T=$ beta actin; $Y W H A Z=14-3-3$ protein zeta/delta; $A H R=$ aryl hydrocarbon receptor; CD9=Cluster of differentiation 9; HSP70=70 kDa heat shock protein; IFNY=interferon gamma; LYN1=Lck/Yes novel tyrosine kinase; MAPKK3=mitogenactivated protein kinase kinase; SLAM=signaling lymphocytic activation molecule; TGFß1=transforming growth factor beta 1. 
25,000 $\mu \mathrm{g} / \mathrm{L} \mathrm{EE}_{2}+\mathrm{LPS}$, but significantly downregulated when LPS was not present (Figure 1A, Table 2). These results are in accordance with previous work demonstrating an upregulation of LYN in murine macrophages after LPS as well as IFN $\gamma$ stimulation..$^{23}$ Effects on LYN1 expression very strongly correlated with AHR expression changes $(r=0.809)$ and moderately to strongly correlated with expression changes of MAPKK3 $(\mathrm{r}=0.546)$ and SLAM $(\mathrm{r}=-0.680)$, respectively (Table 3$)$.

Mitogen-activated protein kinase kinase 3 (MAPKK3) activates MAPK3, a protein involved in the regulation of cellular processes such as proliferation and differentiation in lymphocytes. ${ }^{24}$ MAPKK3 mRNA was upregulated in response to $25,000 \mu \mathrm{g} / \mathrm{L}$ $\mathrm{EE}_{2}+$ LPS exposure, but not when the mitogen LPS was not present (Figure 1A, Table 2 ). A change in the MAP kinase pathway could impact both $\mathrm{B}$ cell receptor or $\mathrm{T}$ cell receptor signaling and $\mathrm{T}$ cell development. ${ }^{25-27}$ MAPKK3 expression changes correlated with expression changes in four other genes (Table 3). Moderate positive and negative correlations were observed with CD9 ( $\mathrm{r}=-0.593)$, LYN1 $(\mathrm{r}=0.546)$, SLAM $(r=-0.568)$ and TGFß1 $(r=0.519)$.

The observed downregulation of the transmembrane protein CD9 at 25,000 $\mu \mathrm{g} / \mathrm{L}$ $\mathrm{EE}_{2}+$ LPS is potentially related to the inactivation of histone deacetylases by LPS. ${ }^{28}$ The Spearman rank order correlation analysis revealed CD9 expression changes correlation only with one other gene (MAPKK3, moderate negative correlation, $\mathrm{r}=-0.593$ ) (Table 3).
TGFß1, a cytokine involved in cell growth, proliferation, differentiation and apoptosis, is the only gene affected by $\mathrm{EE}_{2}$ alone, but not $\mathrm{EE}_{2}+$ LPS. A moderate correlation was observed with MAPKK3 $(\mathrm{r}=0.519)$ (Table 3).

As the differential gene expression patterns revealed (Figure 1A), it is crucial to test the immunotoxicity of a compound with and without stimulation from a potential pathogen like LPS, since immunotoxicity of a compound can vary quite considerably in the two exposure scenarios.

Viability of the harbor seal 11B7501 B lymphoma cell line after $24 \mathrm{~h}$ was $91 \pm 3 \%$ in the negative controls and $83 \pm 2 \%$ in the negative controls of cells exposed with LPS (Figure 1C). The cell line was significantly impacted only in one exposure at $25,000 \mu \mathrm{g} / \mathrm{L} \mathrm{EE}_{2}$ without LPS reducing it to $76 \pm 8 \%$. It is problematic to conclude environmentally relevant effects of $\mathrm{EE}_{2}$ on gene expression of harbor seal lymphocytes in this study, since the maximum dose tested was quite high. Furthermore, it should be investigated to what extent hormone levels in FBS might have influenced the bioavailability of $\mathrm{EE}_{2}$ to the cells, by comparing with charcoal stripped FBS.

Quantitative PCR has rarely been utilized in toxicity testing in the marine mammal immune system, ${ }^{1}$ while the method is more common in other species. To our knowledge this is the second study after Lehnert et al., 2016 that has used this method to assess the toxic mechanisms of action of gene expression in marine mammal immune cells. To date, only few mRNA sequences are known for pinnipeds in comparison to e.g. rodent sequences. It is therefore important to continue the effort to sequence the gene expression transcript and continue using marine mammal lymphocyte cell lines or blood samples from free-ranging animals to further the knowledge of immunotoxic action under contaminant load in marine mammals.

\section{Conclusions}

In conclusion, the observed effect of $\mathrm{EE}_{2}$ depends on the activation status of the lymphocyte, therefore pinpointing complexity of such studies. Indeed, the present results show that two genes were expressed differently with or without LPS. Two genes reacted similarly with or without LPS. One gene was downregulated with $\mathrm{EE}_{2}$ alone, while two genes were downregulated and three upregulated with $\mathrm{EE}_{2}+\mathrm{LPS}$. Correlations of gene expression changes between genes further indicate the complexity of immunotoxic mechanisms and the need for in depth studies elucidating mechanisms of toxic action. We estimate that gene expression analysis is a useful tool in marine mammal immunotoxicological research that should be further developed and used.

\section{Research highlights}

First study to assess effect of $\mathrm{EE}_{2}$ on gene expression profiles in harbor seal leukocytes.

Table 3. Spearman correlation coefficient hemi-matrix for inter-relationships of genes of interest. Significant correlations $(\mathrm{p}<0.05 *$, $\left.\mathrm{p}<0.01^{* *}, \mathbf{p}<0.001^{* * *}, \mathbf{p}<0.0001^{* * * *}\right)$ are in bold.

\begin{tabular}{|c|c|c|c|c|c|c|c|c|c|}
\hline & & AHR & CD9 & HSP70 & IFNg & LYN1 & MAPKK3 & SLAM & TGFb1 \\
\hline AHR & $\begin{array}{l}\mathrm{r} \\
\mathrm{p}\end{array}$ & $\begin{array}{c}1.000 \\
<0.0001\end{array}$ & & & & & \multicolumn{3}{|c|}{ Strength of correlation } \\
\hline CD9 & $\begin{array}{l}\mathrm{r} \\
\mathrm{p}\end{array}$ & $\begin{array}{l}.335 \\
.204\end{array}$ & $\begin{aligned} & 1.000 \\
< & 0.0001\end{aligned}$ & & & & $\begin{array}{l}\text { r } .00-.19 \text { "very } \\
\text { r } .20-.39 \text { "weak } \\
\text { r } .40-.59 \text { "mode }\end{array}$ & & \\
\hline HSP70 & $\begin{array}{l}\mathrm{r} \\
\mathrm{p}\end{array}$ & $\begin{array}{c}.606 \\
.015^{*}\end{array}$ & $\begin{array}{l}-.359 \\
.173\end{array}$ & $\begin{array}{c}1.000 \\
<0.0001\end{array}$ & & & $\begin{array}{l}\text { r } .60-.79 \text { "stron } \\
\text { r } .80-1.0 \text { "very }\end{array}$ & & \\
\hline IFNY & $\begin{array}{l}\mathrm{r} \\
\mathrm{p}\end{array}$ & $\begin{array}{l}.606 \\
.015^{*}\end{array}$ & $\begin{array}{l}-.015 \\
.961\end{array}$ & $\begin{array}{c}.743 \\
.0002 * * *\end{array}$ & $\begin{array}{c}1.000 \\
<0.0001\end{array}$ & & & & \\
\hline LYN1 & $\begin{array}{l}\mathrm{r} \\
\mathrm{p}\end{array}$ & $\begin{array}{c}.809 \\
.0003^{* * *}\end{array}$ & $\begin{array}{l}-.462 \\
.074\end{array}$ & $\begin{array}{l}.379 \\
.148\end{array}$ & $\begin{array}{l}.326 \\
.217\end{array}$ & $\begin{array}{c}1.000 \\
<0.0001\end{array}$ & & & \\
\hline MAPKK3 & $\begin{array}{l}\mathrm{r} \\
\mathrm{p}\end{array}$ & $\begin{array}{l}.337 \\
.201\end{array}$ & $\begin{array}{l}-.593 \\
.017^{*}\end{array}$ & $\begin{array}{l}.041 \\
.880\end{array}$ & $\begin{array}{l}-.132 \\
.619\end{array}$ & $\begin{array}{l}.546 \\
.031 *\end{array}$ & $\begin{array}{c}1.000 \\
<0.0001\end{array}$ & & \\
\hline SLAM & $\begin{array}{l}r \\
p\end{array}$ & $\begin{array}{l}-.483 \\
.059\end{array}$ & $\begin{array}{l}.350 \\
.183\end{array}$ & $\begin{array}{l}-.403 \\
.121\end{array}$ & $\begin{array}{l}-.143 \\
.592\end{array}$ & $\begin{array}{c}-.680 \\
.005 * *\end{array}$ & $\begin{array}{l}-.568 \\
.023^{*}\end{array}$ & $\begin{aligned} & 1.000 \\
< & 0.0001\end{aligned}$ & \\
\hline TGFß1 & $\begin{array}{l}\mathrm{r} \\
\mathrm{p}\end{array}$ & $\begin{array}{l}.236 \\
.377\end{array}$ & $\begin{array}{l}.003 \\
.994\end{array}$ & $\begin{array}{l}-.336 \\
.200\end{array}$ & $\begin{array}{l}-.339 \\
.196\end{array}$ & $\begin{array}{l}.483 \\
.060\end{array}$ & $\begin{array}{l}.519 \\
.041 *\end{array}$ & $\begin{array}{c}-.158 \\
.549\end{array}$ & $\begin{array}{c}1.000 \\
<0.0001\end{array}$ \\
\hline
\end{tabular}


- Development and validation of mRNA primers for harbor seal.

- Gene expression of selected sequences varied in a dose-response depended manner.

\section{References}

1. Lehnert K, Ronnenberg K, Weijs L, Covaci A, Das K, Hellwig V, et al. Xenobiotic and Immune-Relevant Molecular Biomarkers in Harbor Seals as Proxies for Pollutant Burden and Effects. Archiv Environ Contam Toxicol 2016;70:106-20.

2. Harwood J. Marine mammals and their environment in the twenty-first century. J Mammal 2001;82:630-40.

3. Weijs L, Das K, Siebert U, Neels H, Blust R, Covaci A. PCBs, PBDEs and their hydroxylated metabolites in serum of free-ranging harbour seals (Phoca vitulina): levels and profiles. Organohalogen Compounds 2008;70: 000837.

4. Ross P, DeSwart R, Addison R, Van Loveren H, Vos J, Osterhaus A. Contaminant-induced immunotoxicity in harbour seals: Wildlife at risk? Toxicology 1996;112:157-69.

5. Das K, Siebert U, Gillet A, Dupont A, Dipoi C, Fonfara S, et al. Mercury immune toxicity in harbour seals: links to in vitro toxicity. Environ HealthGlob 2008;7.

6. Kleinert C, Lacaze E, Mounier M, De Guise S, Fournier M. Immunotoxic effects of single and combined pharmaceuticals exposure on a harbor seal (Phoca vitulina) B lymphoma cell line. Marine Pollution Bulletin 2017 [Epub ahead of print].

7. Kleinert C, Mournier M, Fortier M, Brousseau P, De Guise S, Fournier M. Several pharmaceuticals impaired harbor seal lymphocytes (Phoca vitulina) in vitro. J Xenobiotics 2013;3(1S):5.

8. Allinson M, Shiraishi F, Salzman S, Allinson G. In vitro and immunological assessment of the estrogenic activity and concentrations of 17beta-estradiol, estrone, and ethinyl estradiol in treated effluent from 45 wastewater treatment plants in Victoria, Australia. Archiv Environ Contam Toxicol 2010;58:57686.
9. Ternes T, Stumpf M, Mueller J, Haberer K, Wilken R, Servos M. Behavior and occurrence of estrogens in municipal sewage treatment plants - I. Investigations in Germany, Canada and Brazil. Sci Total Environ 1999;225:8190 .

10. Kolpin D, Furlong E, Meyer M, Thurman E, Zaugg S, Barber L, et al. Pharmaceuticals, hormones, and other organic wastewater contaminants in US streams, 1999-2000: a national reconnaissance. Environ Sci Technol 2002;36:1202-11.

11. Gelsleichter J. Evaluating the risks that pharmaceutical-related pollutants pose to Caloosahatchee River wildlife: observations on the bull shark, Carcharhinus leucas. Fort Myers: Charlotte Harbor National Estuary Program; 2009.

12. Medina K, Strasser A, Kincade P. Estrogen influences the differentiation, proliferation, and survival of early Blineage precursors. Blood 2000;95:2059-67.

13. Grimaldi C, Cleary J, Dagtas A, Moussai D, Diamond B. Estrogen alters thresholds for B cell apoptosis and activation. J Clin Investig 2002;109:162533.

14. Yakimchuk K, Iravani M, Hasni M, Rhonnstad P, Nilsson S, Jondal M, et al. Effect of ligand-activated estrogen receptor beta on lymphoma growth in vitro and in vivo. Leukemia 2011;25:1103-10.

15. Lehnert K, Muller S, Weirup L, Ronnenberg K, Pawliczka I, Rosenberger $\mathrm{T}$, et al. Molecular biomarkers in grey seals (Halichoerus grypus) to evaluate pollutant exposure, health and immune status. Marine Pollut Bull 2014;88:311-8.

16. Müller S, Lehnert K, Seibel H, Driver J, Ronnenberg $\mathrm{K}$, Teilmann $\mathrm{J}$, et al. Evaluation of immune and stress status in harbour porpoises (Phocoena phocoena): can hormones and mRNA expression levels serve as indicators to assess stress? BMC Vet Res 2013;9.

17. Weirup L, Müller S, Ronnenberg K, Rosenberger T, Siebert U, Lehnert K. Immune-relevant and new xenobiotic molecular biomarkers to assess anthropogenic stress in seals. Marine Environ Res 2013;92:43-51.

18. Frouin H, Fortier M, Fournier M. Toxic effects of various pollutants in 11B7501 lymphoma B cell line from harbour seal (Phoca vitulina). Toxicology 2010;270:66-76.

19. Kakuschke A, Prange A. The influence of metal pollution on the immune system a potential stressor for marine mammals in the North Sea. Int J Comparat Psychol 2007;20:2.

20. Fonfara S, Kakuschke A, Rosenberger T, Siebert U, Prange A. Cytokine and acute phase protein expression in blood samples of harbour seal pups. Marine Biol 2008;155:337-45.

21. Pacheco A, Cardoso C, Moraes M. IFNG+874T/A, IL10-1082G/A and TNF-308G/A polymorphisms in association with tuberculosis susceptibility: a meta-analysis study. Hum Genet 2008;123:477-84.

22. McCarthy A, Shaw M, Jepson P, Brasseur S, Reijnders P, Goodman S. Variation in European harbour seal immune response genes and susceptibility to phocine distemper virus (PDV). Infect Genet Evol 2011;11:1616-23.

23. Boulet I, Ralph S, Stanley E, Lock P, Dunn A, Green S, et al. Lipopolysaccharide-and interferongamma-induced expression of hck and lyn tyrosine kinases in murine bone marrow-derived macrophages. Oncogene 1992;7:703-10.

24. Neale J, Kenny T, Gershwin M. Cloning and sequencing of protein kinase cDNA from harbor seal (Phoca vitulina) lymphocytes. Clin Devel Immunol 2004;11:157-63.

25. Alberolaila J, Forbush K, Seger R, Krebs E, Perlmutter R. Selective requirement for map kinase activation in thymocyte differentiation. Nature 1995;373:620-3.

26. Li W, Whaley C, Mondino A, Mueller D. Blocked signal transduction to the ERK and JNK protein kinases in anergic $\mathrm{CD} 4(+) \mathrm{T}$ cells. Science 1996;271:1272-6.

27. Abbas A, Lichtman A. Cellular and molecular immunology. 5 ed. Philadelphia, PA: Elsevier Science, Saunders; 2003.

28. Jin Y, Tachibana I, Takeda Y, He P, Kang S, Suzuki M, et al. Statins decrease lung inflammation in mice by upregulating tetraspanin CD9 in macrophages. PLoS One 2013;8:9. 